\title{
Learners' Beliefs About Corrective Feedback in the Language Classroom: Perspectives from Two International Contexts
}

Eva Kartchava

This study compared the beliefs college-level students hold about corrective feedback in different learning contexts: English as a second language (Canada, $n=$ 197) and English as a foreign language (Russia, $n=224)$. The participants completed a 40-item questionnaire that dealt with various aspects of feedback found in the literature. While the factor analyses revealed underlying beliefs that were shared by the two populations, the Mann-Whitney-Wilcoxon test identified aspects that differed from one setting to another. To determine possible effects of the background factors, these were correlated with the average belief scores calculated for each participant. The results validate the questionnaire, point to certain background factors that may predict beliefs, and suggest that some beliefs about feedback may be shared across contexts.

Cette étude a comparé les croyances qu'ont des étudiants universitaires par rapport à la rétroaction corrective dans divers contextes d'apprentissage: anglais langue seconde (Canada, $n=197$ ) et anglais langue étrangère (Russie, $n=224$ ). Les participants ont complété un questionnaire à 40 items portant sur divers aspects de la rétroaction puisés dans la littérature spécialisée. Alors que des analyses factorielles ont révélé des croyances communes aux deux groupes, le test Wilcoxon-Mann-Whitney a identifié des aspects qui distinguaient les deux milieux d'apprentissage. Pour déterminer les effets possibles de ces facteurs fondamentaux, nous avons évalué la corrélation entre les résultats moyens sur les croyances tels que calculés pour chaque participant. Les résultats obtenus confirment le questionnaire, révèlent certains facteurs de base qui pourraient prédire les croyances et indiquent que certaines croyances sur la rétroaction se retrouvent dans différents contextes.

KEYWORDS: learners' beliefs, corrective feedback, language learning, English as a second language (ESL), English as a foreign language (EFL)

Learner beliefs, defined as learners' metacognitive knowledge about learning (Wenden, 1999), are seen as "significant learner characteristics to take into account when explaining learning outcomes" (Dörnyei \& Ryan, 2015, p. 187) because they shape and affect the way learners go about the task of learning (e.g., Breen, 2001; Fox, 1993; Horwitz, 1985, 1999; Mori, 1999; Tanaka, 2004). Early research on beliefs has not only identified various beliefs that 
learners hold about language acquisition, but also revealed factors that could shape those beliefs. These may include motivation, anxiety, self-regulation, learner autonomy, gender, language proficiency, and strategy use (e.g., Cotterall, 1999; Horwitz, 1990; Peacock, 1999; Siebert, 2003; Tanaka \& Ellis, 2003; Wenden, 1991, 1999; Yang, 1999). There is also evidence that certain beliefs are common among learners, teachers, target languages, cultures, instructional settings, and age groups (e.g., Chavez, 2007; Horwitz, 1999; Peacock, 2001; Schulz, 1996, 2001). Today, however, learner beliefs are no longer seen as "stable mental representations that are fixed a priori constructs" (Kalaja \& Barcelos, 2003, p. 2) but rather as highly dynamic because they can change in light of one's situation, emotional state, and company (Barcelos \& Kalaja, 2011). Understanding learner beliefs is, then, important for teachers and learners alike. This is especially so in light of Dörnyei and Ryan's (2015) prediction that in the next decade, research into learner beliefs may help to explain factors behind learners' motivation, aptitude, and affect (p. 191).

While numerous studies have investigated learner beliefs about language learning as a whole, a limited number of inquiries have focused on learner beliefs about specific areas of language study (e.g., the teaching/learning of grammar, pronunciation, vocabulary; Jean \& Simard, 2011; Loewen et al., 2009; Simon \& Taverniers, 2011). Such investigations are necessary because they can reveal students' ideas about effective language instruction, which, by extension, may lead to increased learning. The current study aimed to identify what second (L2) and foreign (FL) language learners believe about corrective feedback $(\mathrm{CF})$ - defined as any teacher move aimed to alert the learner to the presence of an error (Carroll \& Swain, 1993) - and whether these beliefs are similar across two specific contexts of Canada and Russia. Knowing what learners think about CF will help teachers to plan for and present information about learners' phonological, grammatical, or lexical accuracy that is in line with their contextually specific expectations and needs. After all, the more teachers know about their students' preferences, the more likely teachers are to understand how they handle, or should handle, "unplanned aspects of teaching" such as CF (Basturkmen, 2012). For learners, understanding their own beliefs about CF will help them recognize how CF may benefit them and what they can do to learn from the supplied feedback. Finally, while research into learners' beliefs about CF has shown that learners as a whole view CF favourably, there is evidence that the instructional context as well as learners' cultural and language learning backgrounds can affect both the degree to which learners may want to be corrected (Loewen et al., 2009; Schulz, 2001; Yang \& Kim, 2011) and the type of CF techniques they may deem useful.

Although some studies have considered the importance learners attribute to specific corrective techniques or to their effectiveness (e.g., Brown, 2009; Yoshida, 2008), none have compared beliefs about CF and about specific CF techniques held by different populations of learners. The need for such a comparison is precipitated by the different instructional approaches employed in 
various settings and the place of CF within them. That is, FL settings often involve extensive focus on form whereas L2 contexts tend to prioritize meaning over form (Nassaji \& Fotos, 2011). This, in turn, affects teachers' approaches to $\mathrm{CF}$, with some choosing to address every error and others opting for selective or no attention to form (Lyster, Saito, \& Sato, 2013). When CF is provided, many teachers resort primarily to one technique (Havranek, 2003; Panova \& Lyster, 2002; Sheen, 2004; but see Lyster et al., 2013), and some find it challenging to consistently provide feedback in response to certain linguistic targets (Allen, Swain, Harley, \& Cummins, 1990; Nicholas, Lightbown, \& Spada, 2001). Given that, as a rule, language learners expect to receive information about the grammaticality of their interactions, not providing or limiting it may result in the possible mismatch between "students' and teachers' belief systems [which] could be harmful to foreign and second language learning" (Russell, 2009, p. 28) and may lead to decreases in learner motivation and a slump in teacher credibility (Horwitz, 1990; Nunan, 1989). In an effort to determine the role of context on language learners' perceptions about $\mathrm{CF}$, this study first identified and then compared the views that Canadian francophone (L2) and Russian (FL) learners of English held about CF in general as well as in relation to specific feedback techniques.

\section{Literature Review}

Corrective feedback plays an important role in the language acquisition process (Li, 2010; Lyster \& Saito, 2010; Mackey \& Goo, 2007; Russell \& Spada, 2006). Specifically, CF allows teachers to provide information about the accuracy of learners' production by raising awareness of the formal aspects of an L2 in the input. There are generally two types of CF techniques: inputproviding or output-pushing (Ellis, 2006). While the former includes CF techniques that provide the target form in response to an error (i.e., recasts and explicit correction), the latter category alerts learners to the presence of an error, pushing them to recognize the corrective intent behind the $\mathrm{CF}$ and to self-correct (i.e., prompts). The effectiveness of each category has been extensively debated, with some suggesting that prompts generate more learning than recasts in the classroom context (e.g., Ammar \& Spada, 2006; Lyster, 2004) and others maintaining that recasts are either more effective than no feedback (e.g., Han, 2002; Leeman, 2003; Mackey \& Philp, 1998) or comparable to prompts (Lyster \& Izquierdo, 2009; McDonough, 2007) in the laboratory context. It is, however, possible that the effectiveness of these CF types is, in part, mitigated by learner beliefs about $\mathrm{CF}$ and its techniques.

Learner beliefs were first introduced into the L2 literature by Horwitz, who investigated the relationship between student attitudes and L2 outcomes. Using the Beliefs About Language Learning Inventory (BALLI), which consists of 34 statements $^{1}$ that assess student beliefs in five areas-(a) the difficulty of language learning, (b) foreign language aptitude, (c) the nature 
of language learning, (d) language learning and communication strategies, and (e) motivation and expectations-Horwitz $(1987,1988)$ confirmed that learners of various linguistic and cultural backgrounds share certain beliefs about learning. Other studies showed that learners' epistemological beliefs (i.e., beliefs about the nature of learning) differ from those about language learning (Mori, 1999), suggesting that learners perceive learning in general differently from learning about specific subjects and concepts. Loewen et al. (2009), for example, showed that learners view grammar instruction and CF as distinct categories, and the authors have called for future research to consider this differentiation.

The studies that have examined learner beliefs about CF have thus far allocated a limited number of questions to the topic. Schulz's $(1996,2001)$ questionnaire on teacher and learner attitudes about the role of grammar study and CF in FL learning, for example, contained a mere seven questions on the role of $\mathrm{CF}$ in language learning, of which four dealt with the role of feedback in general, two with students' attitudes toward feedback on written errors, and only one with learners' attitudes toward oral CF. Similarly, Loewen et al. (2009) used a 37-item Likert-scale questionnaire with four openended prompts to investigate the beliefs of 754 L2 and FL learners about the role of grammar instruction and error correction. Their questionnaire focused primarily on the role, efficacy, and importance of grammar, thus giving error correction lesser weight. More recently, Jean and Simard's (2011) questionnaire exploring the beliefs regarding the learning and teaching of grammar of 2,321 L2 high school learners of English and French and 45 of their teachers in Quebec, Canada, included 14 Likert-scale items, only 3 of which focused explicitly on the role of CF. More specifically, one question probed the level of importance participants attributed to accuracy in general, another focused on the preferred timing of feedback on oral grammar errors, and the third explored the types of errors learners wanted to have corrected in their written work. Clearly, it is premature to claim that the limited narrative regarding $\mathrm{CF}$ in these studies can begin to tell the story of learner beliefs about CF.

What these studies do show, however, is that learners and teachers differ in their views about CF provision. Overall, teachers tend to provide fewer corrections than learners expect. Schulz (1996), for example, compared the responses of 824 American FL students and 92 teachers and found that although both groups converged on the importance of feedback on written errors (citing agreement of $93 \%$ and $97 \%$, respectively), their opinions about oral feedback varied drastically; the students overwhelmingly welcomed feedback to their spoken errors $(90 \%)$, but the majority of the teachers $(70 \%)$ did not see it as important. A similar pattern of results emerged in a followup study when Schulz (2001) administered the same questionnaire to 607 Colombian FL students and their 122 teachers. Like their American counterparts, these learners strongly believed in the importance of feedback on speaking $(97 \%)$, but $61 \%$ of their teachers failed to share this opinion. The 
teachers in Jean and Simard's (2011) study also reported their belief that only those errors that impede communication need to be addressed.

Despite the importance of context in language learning, few studies surveyed learners from different settings about their CF preferences. Loewen et al. (2009) is the only study that has attempted to do so, reporting that while learners of English (the majority of whom had a Korean [51\%] or Chinese [20\%] L1) expressed strong aversion to CF and accuracy in grammar, $81 \%$ of English L1 learners of foreign languages (e.g., Arabic, Chinese, Spanish) preferred $\mathrm{CF}$ and viewed positively the need for grammatical accuracy in language learning. The authors explained the findings in light of the learners' past and current language learning experiences. That is, the learners of English, being immersed in the L2, preferred to practice their communicative skills in the target language more than attend to the correctness of their utterances - possibly because of the high amount of grammar instruction and $\mathrm{CF}$ they had been subjected to in the past. Learners of foreign languages, on the other hand, in the absence of opportunities to use the target language in authentic situations outside the classroom, placed more importance on grammar instruction and CF. While telling, these findings are limited to language learners in one university in the United States, signaling a need for more studies of this kind from various parts of the world. Finally, to date, there is a paucity of research into learners' beliefs about specific CF techniques. Two studies that have investigated the topic produced varied results, with some learners wanting to be corrected by way of prompts when they knew the correct answer (Yoshida, 2008) and others (especially advanced learners) preferring recasts (Brown, 2009). With these considerations in mind, the current study addressed the following research questions:

1. What do second and foreign language learners believe about corrective feedback in general and about specific CF techniques?

2. Are there differences in beliefs between learners of English in Canada and those in Russia?

3. What are the sources of those beliefs?

\section{Method}

\section{Participants}

The study participants were all attending public postsecondary colleges, with one group located in a predominantly French-speaking area of Montreal, Canada $(n=197)$, and the other in St. Petersburg, Russia $(n=224)$. All the participants were asked to complete a questionnaire survey in the first week of classes. The participants had a high-beginner proficiency in English, as determined by the English language placement test administered by each college. The Montreal-based participants (129 females, 68 males, mean age: 20.75 years) were students in a French-medium college enrolled 
in their second ESL course. ${ }^{2}$ While several participants spoke more than one language (mode: 2 ), the majority $(78.8 \%)$ reported French as their L1. Those who claimed a different L1 (21.2\%) indicated that they predominantly used French at home, which, in fact, is in line with the 80\% of allophones (those with some knowledge of either English or French) who, having immigrated to Quebec between 2006 and 2011, claimed to speak primarily French at home (Statistics Canada, 2011). Prior to the study, the participants received ESL instruction for three years in primary school (approximately 120 hours) and five years in high school (approximately 670 hours). When probed about the context in which they learned English, the majority indicated the "classroom" ( $n=186 ; 94.4 \%$ of the total), which could suggest that their contact with the L2 was limited outside the classroom. Even if they had contact with English (American and Canadian) popular culture, it may not have been for the purpose of learning the language, since much of the literature, music, television, and filmography produced in English is available and consumed across Quebec in French translation (Winer, 2007). This demographic was of special interest, as they lived and studied in a predominantly French environment but were required to study English as a school subject within the wider ESL context of Canada.

The Russian group of college learners (mean age: 19.74 years) were also attending a required English course. The participants (157 females, 67 males) reported having had, on average, 1,023 hours of English instruction, with much of it $(98 \%)$ taking place in the classroom. The majority $(97.3 \% ; n=218)$ spoke Russian as their first language, with only six participants reporting Armenian, Tadjik, or Turkmen languages as their mother tongue. Knowledge of one language was the norm (mode: 1.5 ), with very few participants reporting experience with two languages or more. Similar to their Canadian counterparts, the Russian participants reported minimal contact with English outside the classroom, with many consuming English-based printed and other media in translation. Moreover, very few of the participants reported having travelled abroad or having used English as a means of communication with non-Russian-speaking interlocutors.

\section{Learning Contexts}

While the two contexts share some commonalities, they also differ in the subscribed view of language, its role in the everyday, and the importance and/or effectiveness of foreign language (specifically, English) instruction. In the traditional ESL/EFL dichotomy, ESL has been defined as "the teaching of English ... in countries where English is the major language of commerce and education, [where it is likely to be heard and] spoken on a regular basis in settings beyond the classroom" (Murphy \& Byrd, 2001, p. 21, cited in Mattioli, 2004). EFL refers to the teaching contexts that the above definition of ESL does not cover and where learners have limited or no opportunities to interact with English outside the classroom (Mattioli, 2004). ${ }^{3}$ 


\section{Quebec, Canada}

A small minority in predominantly English-speaking North America, Quebec's population is primarily French-speaking (78\%) with pockets of English speakers $(7.6 \%)$ and speakers of first languages other than English or French (12.3\%) (Statistics Canada, 2011). Up until the Quiet Revolution of the 1960s, English played a prominent role in the province, and knowledge of French was not required to obtain lucrative employment or to successfully settle in the province. This changed with the rise of a movement for Quebec separation from the rest of Canada, which demanded recognition of the people of Quebec as a nation with its own unique ethnic identity and language (Winer, 2007). One key piece of legislation resulting from this movement was Bill 101 (the Charter of the French Language), which, in 1977, made French the language of education, the workplace, and public signage province-wide.

Both French and English are taught in public schools, but their programs and implementations differ. While French as a second language and French immersion are taught in both English- and French-medium public schools, only English as a second language programs are allowed in French-medium schools. English immersion programs, where English is the medium of instruction for content courses, are prohibited in Quebec (Gouvernement du Québec, 2007a, 2007b, 2007c). This means that native or proficient speakers of English who are not eligible to study in English must attend French-language schools. Still, English is a required subject in French primary and secondary schools as well as in French postsecondary colleges; this is also the case for French in English schools and colleges. However, English is not necessary for many jobs or life situations in the province and is no longer a strong motivator for travel to and employment in English areas because "Quebec francophones are 10 times less likely to leave the province than Quebec anglophones" (Bruemmer, 2006, cited in Winer, 2007, p. 503). This makes Quebec's situation unusual in that English is "both a second and a foreign language, depending on one's political orientation, geographic location, family background, and other factors" (Winer, 2007, p. 494).

The actual use of English in the province varies from one community to another. In suburban Montreal communities, for example, English is widely used in daily life, but this is not the case for smaller Quebec towns, where few speak English and much of public life is conducted in French. Even within the greater Montreal area, there is variability in the use of English with predominantly English- and French-speaking communities existing side by side. Since the francophone participants in this study were all attending a Frenchmedium college located in a predominantly French-speaking area of Montreal and had access to English outside the classroom, this population has been operationalized here as "ESL." 


\section{Russia}

For the Russian participants, English is very much a foreign language and is taught as such in schools and various postsecondary educational institutions. The teaching of foreign languages was a staple of the former Soviet Union, with some children being exposed to a foreign language in preschool. The majority, however, first came into contact with a foreign language - typically English - at the age of 10 and continued with instruction well into high school. As a rule, those who chose to pursue higher education prolonged their exposure to foreign language instruction for at least three years of a five-year degree or until graduation from specialized university programs such as international affairs, translation studies, and foreign language pedagogy (Dunstan, 1994). Today, the model remains largely unchanged, although more schools offer early foreign language instruction (e.g., starting in Grade 2 , at 7-8 years of age) and some offer intensive language study at home and through international exchanges.

In Russia's past, knowledge of an additional language, especially a European language (Ushinsky, 1988), was seen as the mark of a well-educated and well-rounded person. The study of foreign languages was an intellectual activity and taught using the Grammar-Translation method, which largely involved translating a text from a foreign language to Russian and vice versa. In today's post-Soviet Russia, foreign language education still enjoys prominence in the national education system, but the goals for language learning have become more tangible and usually centre on obtaining lucrative employment with a foreign company operating within Russia, travelling abroad, and being able to interact with people from other countries. Advances in technology and increased access to digital platforms have also intensified the need for foreign language knowledge; this is especially relevant in light of the fact that not all digital information is available in translation. Finally, there is a tendency for Russian media to use English and a hybrid mix of Russian and English, especially in TV commercials, "as an external code to attract attention of the customers, as a source of cross-cultural creativity, and as a marker of Westernization, internationalism, modernization, innovation, and prestige" (Ustinova \& Bhatia, 2005, p. 495).

\section{Materials}

\section{Beliefs Questionnaire}

A two-part questionnaire was created in order to elicit responses to statements about CF and CF techniques (see Appendix). To ensure comprehension, the questionnaire was translated into French and Russian; the accuracy was verified by several French L1 and Russian L1 speakers. The items were randomized prior to the survey administration, which took place during the first week of classes. The questionnaire had been piloted on a similar pop- 
ulation and validated in previous research (Kartchava \& Ammar, 2014). In Part 1, demographic information on the participants was gathered, including their linguistic background. For each of the languages spoken, the participants indicated: (a) where they learned it (i.e., classroom, home, other); (b) the number of years they had been speaking it; and (c) on a scale of "poor" to "excellent," how well they spoke, wrote, listened, and read in each. Part 2 of the questionnaire contained 40 statements dealing with various aspects of CF based on the theoretical and empirical findings in the CF literature. Specifically, these touched on expectations for feedback and its importance, as well as the timing, amount, mode, and manner in which CF should be delivered. Statements about the two corrective techniques of interest (recasts and prompts) were also included. The participants were asked to indicate on a scale of 1 to $5(1=$ strong disagreement and $5=$ strong agreement $)$ the degree to which they agreed with each statement.

\section{Data Analysis and Results}

\section{Research Question 1}

To determine learners' beliefs about corrective feedback and the specific CF techniques (RQ1), the participants' responses on Part 2 of the questionnaire were subjected to a factor analysis, a technique frequently used to identify underlying constructs that are common to a particular sample of participants (Field, 2005). An exploratory factor analysis was chosen because there is currently no established theory as to what and how many factors underlie English learners' beliefs about CF (DeCoster, 1998). Principle Components Analysis (PCA) on the 40 items (SPSS, Version 22) was performed for each of the groups. The suitability of the data samples was confirmed by the KaiserMeyer-Oklin value of .821 for the Canadian group and the value of .827 for the Russian set and by the statistically significant Bartlett's Test of Sphericity (Canadian sample: $\chi 2=2968.542, p<.001$; Russian sample: $\chi 2=3227.721, p<$ $.001)$. Cronbach's alpha for the 40 -item scale was .84 for both groups, indicating internal item consistency.

The factor analysis for the Canadian sample revealed five components accounted for $44.3 \%$ of the total variance, with Component 1 contributing $22.21 \%$, Component 2 contributing 8.23\%, Component 3 contributing 5.2\%, Component 4 contributing $4.5 \%$, and Component 5 contributing $4.2 \%$. It is important to note that factor loadings of less than .40 were suppressed to ensure a more obvious pattern matrix with identifiable themes. To aid in the interpretation of the five components, oblim rotation was implemented. As Table 1 shows, 18 items loaded on Factor 1, 7 items on Factor 2, 3 items on Factor 3, 2 items on Factor 4, and 7 items loaded on Factor 5. To label each of the factors, the highest loading items for each were identified. Because the highest loading items for Factor 1 (Items 23, 20, and 25) were concerned with 


\section{Table 1}

Canadian Data: Rotated Factor Loadings for PCA with Oblim Rotation of Five Factor Solution of Learner Beliefs About CF Items

\begin{tabular}{|c|c|c|c|c|c|}
\hline \multirow[b]{2}{*}{ Questionnaire Item } & \multicolumn{5}{|c|}{ Component } \\
\hline & 1 & 2 & 3 & 4 & 5 \\
\hline 23. & .714 & & & & \\
\hline 20. & .694 & & & & \\
\hline 25. & .692 & & & & \\
\hline 16. & .663 & & & & \\
\hline 17. & .634 & & & & \\
\hline 26. & .597 & & & & \\
\hline 22. & .587 & & & & \\
\hline 13. & .587 & & & & \\
\hline 18. & .587 & & & & \\
\hline 29. & .543 & & & & \\
\hline 7. & .537 & & & & \\
\hline 14. & .532 & & & & \\
\hline 30. & .513 & & & & \\
\hline 10. & .502 & & & & \\
\hline 9. & .454 & & & & \\
\hline 21. & .439 & & & & \\
\hline 4. & & .635 & & & \\
\hline 38. & & .600 & & & \\
\hline 27. & & .585 & & & \\
\hline 35. & & .559 & & & \\
\hline 28. & & .526 & & & \\
\hline 31. & & .503 & & & \\
\hline 2. & & .481 & & & \\
\hline 3. & & & -.715 & & \\
\hline 15. & & & -.699 & & \\
\hline 34. & & & -.639 & & \\
\hline 12. & .496 & & & -.558 & \\
\hline 11. & .511 & & & -.537 & \\
\hline 33. & & & & & -.648 \\
\hline 36. & & & & & -.647 \\
\hline 40. & & & & & -.638 \\
\hline 39. & & & & & -.580 \\
\hline 32. & & & & & -.529 \\
\hline 37. & & & & & -.471 \\
\hline 6. & & & & & -.466 \\
\hline
\end{tabular}

Note. Major loadings for each item are bolded. 
the importance and expectation of $\mathrm{CF}$, this factor was labelled "Importance and Expectation of CF." The highest loading items on Factor 2 (Items 4, 38, and 31) were concerned with the types of errors that should be corrected, so that factor was named "Error Types to Correct." As the three items in Factor 3 (Items 3, 15, and 34) represented the belief that the best way to provide CF is through prompts, the factor was named "Prompts as CF Method." Because only two statements loaded onto Factor 4 (Items 12 and 11), they were combined with those in Factor 5; as well, the Factor 4 items were both about recasts as a CF method, and the highest loaded items in Factor 5 (Items 33, 36,39 , and 40) also addressed recasts. As such, the last factor was named "Recasts as CF Method."

The picture was remarkably similar for the Russian group (Table 2), where the participants' responses produced four factors that also were concerned with the importance and expectation of CF (Factor 1), types of errors to be corrected (Factor 2), prompts (Factor 3), and recasts (Factor 4) as CF methods. The four factors explained $40.5 \%$ of the total variance, with Factor 1 contributing $21.04 \%$, Factor 2 contributing 9.13\%, Factor 3 contributing 5.8\%, and Factor 4 contributing $4.5 \%$. Interestingly, the seven items that loaded onto Factor 2 in the Russian and Canadian data sets include the same statements (Items $2,4,27,28,31,35$, and 38), albeit with slightly different loadings.

\section{Research Question 2}

Given the apparent similarities between the two belief structures yielded by the PCA, it was necessary to determine whether these structures were in fact similar (RQ2). To do so, the nonparametric Mann-Whitney-Wilcoxon $(\mathrm{MWW})^{4}$ test was performed, with the null hypothesis being that each of the factors in the two factorial outputs were similar $\left(\mathrm{H}_{0}\right.$ : Factor $r=$ Factor $\left.i\right)$ and the alternative hypothesis stating that these were different $\left(\mathrm{H}_{\mathrm{a}}\right.$ : Factor $\stackrel{r}{r} \neq$ Factor $\left.i\right)$. The null hypothesis was rejected for Factors 2,3 , and $4(p<0.05)$, suggesting that the factors differed between the two groups. However, the high $p$-values ( $p=0.9$ for predicted Russia/Canada and $p=0.1$ for predicted Canada/Russia) meant that there was not enough evidence to reject the null hypothesis for Factor 1. This suggests that similarities observed in the questionnaire responses may be warranted.

\section{Research Question 3}

A multiple regression on the possible relationships between the resulting belief factors and the participants' background information (gathered in Part 1 of the questionnaire) was performed for each sample separately and on both samples together (i.e., combined data). Learner average scores per factor were first calculated, and then each was correlated with the background factors of age, gender, number of languages spoken, proficiency in each language, and proficiency in English. For the Canadian sample, there was only one significant correlation between Factor 5 ("Recasts as CF Method") and gender ( $R^{2}$ 
Table 2

Russian Data: Rotated Factor Loadings for PCA with Oblim Rotation of Four Factor Solution of Learner Beliefs About CF Items

\begin{tabular}{|c|c|c|c|c|}
\hline \multirow[b]{2}{*}{ Questionnaire Item } & \multicolumn{4}{|c|}{ Component } \\
\hline & 1 & 2 & 3 & 4 \\
\hline 22. & .767 & & & \\
\hline 20. & .746 & & & \\
\hline 23. & .718 & & & \\
\hline 25. & .705 & & & \\
\hline 21. & .531 & & & \\
\hline 29. & .525 & & & \\
\hline 7. & .517 & & & \\
\hline 16. & .511 & & & \\
\hline 26. & .506 & & & \\
\hline 32. & .502 & & & \\
\hline 14. & .500 & & & \\
\hline 38. & & .765 & & \\
\hline 31. & & .748 & & \\
\hline 35. & & .748 & & \\
\hline 4. & & .571 & & \\
\hline 28. & & .556 & & \\
\hline 27. & & .533 & & \\
\hline 2. & & .470 & & \\
\hline 12. & & & -.824 & \\
\hline 11. & & & -.809 & \\
\hline 40. & & & -.727 & \\
\hline 18. & & & -.670 & \\
\hline 6. & & & -.571 & \\
\hline 36. & & & -.442 & \\
\hline 24. & & & -.407 & \\
\hline 37. & & & -.402 & \\
\hline 3. & & & & .704 \\
\hline 34. & & & & .628 \\
\hline 33. & & & & .593 \\
\hline 15. & & & & .495 \\
\hline
\end{tabular}

Note. Major loadings for each item are bolded. 
$=0.1277, p \approx 0.06),{ }^{5}$ suggesting that females were less likely to prefer recasts as a correction method. The Russian sample, in contrast, produced two significant correlations. Factor 2 ("Types of Errors to Correct") appeared to be influenced by the participants' gender $\left(R^{2}=0.07483, p \approx 0.05\right)$ and the number of languages they spoke $\left(R^{2}=0.07483, p \approx 0.01\right)$. That is, females and those with the knowledge of more than one language seemed to have an opinion on the types of errors that needed to be corrected when learning an additional language. For the combined data, Factor 1 ("Importance and Expectation of $\left.\mathrm{CF}^{\prime \prime}\right)$ correlated significantly with proficiency in L2 $\left(R^{2}=0.02381, p<0.05\right)$, suggesting that higher proficiency in an L2 amplifies the importance of and preference for $\mathrm{CF}$.

\section{Discussion}

\section{Beliefs About Oral Corrective Feedback}

The factor analyses conducted on the learners' responses to the 40-item questionnaire identified four common factors about CF that the participants in both groups deemed central: (a) Importance and Expectation of CF, (b) Types of Errors to Correct, (c) Prompts as CF Method, and (d) Recasts as CF Method. The resulting pattern suggests that, despite their learning contexts, these high-beginner learners of English believe in the importance of oral CF and differentiate between the types of errors they wish to be corrected in classroom discourse. They also distinguish between various $\mathrm{CF}$ techniques (i.e., recasts and prompts), on the one hand expecting the teacher to supply the correct form in response to an error and, on the other, recognizing the positive role that self-correction prompted by a teacher's cue, comment, linguistic information, or encouragement can bring to their language learning.

The belief in the importance and expectation of $\mathrm{CF}$ in the language classroom (Factor 1) is corroborated by previous research that showed that learners generally prefer to have their errors corrected rather than ignored. This is true of both second (e.g., Cathcart \& Olsen, 1976; Chenoweth, Day, Chun, \& Luppescu, 1983; Jean \& Simard, 2011) and foreign (e.g., Oladejo, 1993; Schulz, 1996, 2001) language learning contexts and is confirmed by the findings of this study. The fact that learners from different instructional settings are united in their quest to receive CF suggests, in the words of Horwitz (1999), that "perhaps there is a world culture of language learning and teaching which encourages learners of many cultural backgrounds to perceive language learning very similarly" (p. 575).

Another interesting similarity is that both groups felt that only those errors that impede comprehension or are recurrent require attention (Factor 2). Selective correction of oral errors was also preferred by EFL learners in Spain (Lasagabaster \& Sierra, 2005), who worried that too much feedback would inhibit their ability to communicate freely. Learners of English in Singapore 
(Oladejo, 1993), however, favoured a comprehensive approach to error correction and did not worry about feelings of frustration or lack of willingness to communicate that oral CF could yield. The opinion on the scope of correction was split among ESL high school learners in Quebec, 54\% of whom wanted to have their oral errors corrected "all the time" and $41 \%$ of whom felt that feedback should be provided only when they "cannot make themselves understood" (Jean \& Simard, 2011, p. 474). Several researchers have suggested that being immersed in the L2 environment is potentially more influential than one's language learning background in predicting positive attitudes toward grammar teaching and CF (Loewen et al., 2009; Schulz, 2001). For example, Loewen et al. (2009) showed that when learners of English as a second language are immersed in the target language environment, they were more likely to focus on communication and worry less about accuracy, which produced negative attitudes towards grammar learning and CF. Their foreign language counterparts (learning Arabic, Chinese, or other foreign languages in the United States) relied more on learning grammar rules and receiving $\mathrm{CF}$, which, by extension, produced more positive attitudes toward grammar and CF. The results of the current investigation, however, appear to indicate that neither of the factors (i.e., language learning background or L2 environment immersion) played a major role in helping the participants to express the need for a selective approach to error correction in the language classroom. In fact, the two groups identified exactly the same seven items for this factor.

At the same time, L2 researchers have provided evidence that "student beliefs about language learning [can] originate from their L2 learning experiences (Almarza, 1996; Horowitz, 1985; Kern, 1995), particularly in secondary school" (Peacock, 2001, p. 187). Thus it is possible that the respondents' past L2/FL learning experiences may have influenced their ability to differentiate between the two CF types of recasts and prompts (Factor 3 and Factor 4). These influences might have originated from the learners' experiences with feedback and the role teachers played in their language learning.

EXPERIENCES WITH CF

It is possible that provision of $\mathrm{CF}$, or lack thereof, can shape one's opinion about the ways in which feedback should be supplied. The preference for recasts as the $\mathrm{CF}$ type may, for example, be explained either by it being the only method in which the participants' errors had been addressed in the classroom, or, in the case of no correction, by it representing the desired $\mathrm{CF}$ technique. If the former, then seeing recasts as the best $\mathrm{CF}$ method is in line with the research that identified them as the most commonly used CF technique across contexts and languages (Lochtman, 2002; Lyster \& Ranta, 1997; Panova \& Lyster, 2002; Sheen, 2004, 2006; Slimani, 1991). This feedback method can also be seen as the most familiar and nonintrusive. The familiar- 
ity may stem not only from learners being exposed to recasts in the L2 classroom, but also from their L1 learning experiences, where recasts are used by parents to clarify the meaning or address the truth value of statements made (Farrar, 1990). Because recasts provide the correct version of what has been said without pointing out the inaccuracy, they may become the technique of choice. Moreover, recasts are especially prominent in native/non-native speaker interactions (Long, 1983, 1996, 2006), where communication breakdowns are signaled by an L2 interlocutor's nonunderstanding of the intended message and the need to comprehend it. In such a context, recasts provide L2 learners with target-like models of the intended message and supply positive evidence about the grammaticality of the L2.

The participants also expressed a preference for prompts. This may be because items that call for self-correction are inherently different from those that have the teacher supply the correct form. Alternatively, it is possible that the recognition of the two feedback techniques speaks to the learners' belief about the importance of variety in the treatment of error. Perhaps the main reason for the choice of the two techniques is that, although learners generally agree on the need for $\mathrm{CF}$, they are not sure which type of feedback would suit them best under what circumstances. This is especially true in the case of oral feedback, as learners agree that CF is important but disagree on the type of feedback that would be most effective (Casciani \& Rapallino, 1991, cited in Loewen et al., 2009). University students in Bang's (1999) study, for example, had positive attitudes toward CF, but their opinions diverged in terms of when and how they were to be corrected.

Some learners, however, do express preference for one CF type over others. For example, the seven Australian learners of Japanese studied by Yoshida (2008) wanted to be given time to self-correct instead of having their errors recast. This was also the case in Mohamed Hassan Mohamed's (2011) study, where she investigated opinions about $\mathrm{CF}$ among French as a foreign language teachers $(n=25)$ and learners $(n=175)$ in Egypt and found that, although the teachers preferred recasts to correct most of their learners' spoken errors, the students did not see recasts as effective and favoured prompts instead. For the most part, the teachers did not promote the practice of student self-correction but rather rushed to recast errors. Similarly, while the teachers in Yoshida (2008) believed in the importance and efficacy of prompts, they often resorted to recasts as these were deemed to promote a "supportive classroom environment" (p. 89).

TEACHERS' ROLE IN LANGUAGE LEARNING

Traditionally, teachers have occupied a central role in the learning process. Thus, it comes as no surprise that, having come into contact with a variety of teachers and teaching approaches, learners have their own ideas about what constitutes effective teaching and learning. For example, if the principles 
of autonomous learning, which encourage students to take control of their learning through the use of a "set of tactics"6 (Cotterall, 1995), are encouraged and implemented in the classroom, then the learners, by consciously monitoring their performance (Stern, 1975), become more self-reliant; they no longer see the teacher as the sole purveyor of successful learning. In this model, the teacher acts as a facilitator, training students to develop awareness of the learning goals, the language, and themselves as language learners (Tudor, 1993). On the other hand, learners exposed to the traditional education system - where the teacher is seen as the figure who "acts as authority on the target language and on language learning, as well as directing and controlling all learning in the classroom" (Cotterall, 1995, p. 197)-tend to rely on the teacher to determine what learning is to be done, to establish the time line in which to achieve set objectives, and to diagnose and treat individual difficulties that may arise (Knowles, 1976). Here, learners are not taught to reflect on the learning they do or on themselves as learners, but are conditioned to assume a "back-seat" role in the process (Cameron, 1990). As a result, learners expect all the knowledge and the monitoring of that knowledge to come solely from the teacher (Kumaravadivelu, 1991). The same is true for CF practices, as learners may be unable to separate the notion of correction from the teachers' role and depend solely on instructors to oversee their progress/performance, resulting in acquiring "beliefs that encourage dependence rather than independence" (Wenden, 1991, p. 55).

The cluster of items that loaded onto Factor 1 in this study seems to suggest that the participants primarily relied on the language teacher for feedback on their performance. Specifically, they expected the teacher to (a) monitor the accuracy of student performance (Question 21); (b) address all the spoken errors students made (Question 29); (c) identify the errors students made in grammar, vocabulary, and pronunciation, and provide corrected forms (Questions 20, 23, 25, and 14); (d) keep students motivated to learn (Questions 7, 16, and 22); and (e) reinforce oral production through feedback (Question 26). This reliance on the teacher may be due to the respondents' instructional settings, their limited exposure to the target language, and their low proficiency. In fact, Victori's (1992) investigation of the learners' views of language learning found that "the more experience in language learning the respondents had, the less likely they were to rely on teachers during the task of language learning" (p. 72).

\section{Sources of Reported Beliefs}

The second main finding of this study relates to the sources of beliefs expressed by the participants. The two groups both believed that increased proficiency in a second/foreign language amplifies the importance of $\mathrm{CF}$ and its expectation in the learning process. While gender appeared to determine the likelihood of recasts being the preferred CF technique for the Canadian 
group, gender and the number of languages spoken influenced attitudes held by the Russian participants about the types of errors that require attention in the language classroom.

It seems understandable that the participants in both ESL and EFL contexts identified a relationship between proficiency and feedback, suggesting that the more experience they had with language learning the more likely they were to appreciate the effect and importance of attention to form. Research has repeatedly shown that not only is provision of CF effective for language learning in general (Li, 2010; Lyster \& Saito, 2010; Mackey \& Goo, 2007; Russell \& Spada, 2006), but also that learners overwhelmingly expect to receive information about how well they express themselves when speaking in a second/foreign language (e.g., Cathcart \& Olsen, 1976; Chenoweth et al., 1983; Jean \& Simard, 2011; Oladejo, 1993; Schulz, 1996, 2001). Moreover, there is evidence that learners of different proficiencies tend to differ in the types of CF strategies they prefer and see as beneficial. For example, in their investigation of the differential effects of prompts and recasts on the acquisition of possessive determiners by young francophone learners of English in Quebec, Ammar and Spada (2006) found that the effectiveness of feedback largely depended on the learner's proficiency level; high-proficiency learners benefited equally from recasts and prompts, whereas their low-proficiency counterparts benefited more from prompts than recasts. Similarly, with older learners, Brown (2009) showed that more advanced learners preferred implicit feedback types that promoted self-directed attention to form and, consequently, self-correction. Furthermore, Philp (2003), in her investigation of the L2 learners' ability to notice recasts during oral interaction with native speakers of English, showed that more advanced learners were more successful at noticing and recalling recasts than their beginner counterparts. Finally, there is evidence that language learning experience tends to affect individuals' beliefs about the process (Banya \& Chen, 1997, cited in Bernat \& Lloyd, 2007). That is, more seasoned language learners are inclined to view the process of language development from a more positive yet realistic vantage point than their less experienced peers, which is a possible explanation for the significant correlation between language learning experience and the importance of $\mathrm{CF}$ found in this study.

Gender appeared to influence two reported beliefs: the types of errors requiring $\mathrm{CF}$ (Factor 2) and recasts as the preferred CF method (Factor 4). Albeit from different learning contexts, it was the female participants in both countries who identified these factors as important. Specifically, the Russian females advocated for a selective approach to feedback, and the Canadian female contingent was least likely to prefer to have its oral errors addressed with recasts. While intriguing, it is premature to draw conclusions from these findings for several reasons. First, as observed by Dörnyei (2005), while gender and age can affect one's success in language learning, they are problematic individual differences (ID) in that "they affect every aspect of SLA process, 
including virtually all the other ID variables" (p. 8). In fact, several researchers (e.g., Bernat \& Lloyd, 2007; Rifkin, 2000; Tercanlığlu, 2005) have argued that not only gender but other factors such as stage of life, context, personality, intelligence, motivation, anxiety, self-efficacy, and many others, alone or in combination, can affect expressed beliefs. Second, there is currently little research investigating male and female beliefs about language learning, and the results are inconsistent. Bernat and Lloyd (2007), for example, have reported on a number of studies that either found significant (Siebert, 2003), little (Bacon \& Finnemann, 1992), or no (Tercanlıoğlu, 2005) differences between the genders. Third, no research on the relationship between gender and learner beliefs about CF currently exists. The only study to date that has tried to measure the impact of gender on a specific area of language learning (i.e., grammar teaching) has been carried out with school-age ESL and French as a second language (FSL) students by Jean and Simard (2011), who found that the females were more receptive to grammar instruction and, to some degree, error correction (83\% versus $74 \%$ ) than the males. Oxford, Nyikos, and Ehrman (1988) were perhaps the first to investigate the popular notion that females are better language learners than men are. Using the research available at the time, they tried to explain the differences between the genders, but later conceded that looking at gender as the variable that determines one's ability to learn another language is an inadequate and, in many regards, crude measure of success (Ehrman \& Oxford, 1990).

Finally, the number of languages spoken significantly correlated with Factor 2 for the Russian sample, suggesting that the more languages individuals know, the more likely they are to have an opinion about the types of errors requiring $\mathrm{CF}$. This is in line with the earlier discussion on selective correction and the relationship between proficiency and feedback, in that extensive experience with various languages helps to shape learners' preferences for instructional methods and learning strategies. This finding is suggestive of a relationship that could be empirically investigated in multilingual contexts.

\section{Conclusion}

This study sought to investigate the beliefs that young adult learners of English in Canada and in Russia held about CF. In line with Basturkmen, Loewen, and Ellis's (2004) definition of "beliefs" - that is, "statements teachers [and students] make about their ideas, thoughts, and knowledge that are expressed as evaluations of what 'should be done,' 'should be the case,' and 'is preferable'" (p. 244) - the results show that the participants in both contexts felt that CF should be done, should be the case, and is preferable in the context of a language classroom. They also expressed preferences about the types of errors requiring teachers' attention and distinguished between feedback techniques. Furthermore, certain background factors appeared to 
predict beliefs both within an instructional setting (i.e., gender, number of languages) and across settings (i.e., proficiency in L2).

These results, however, need to be interpreted with caution in light of the limitations associated with the tool used to identify the beliefs. The participants had to respond to researcher-developed questionnaire items, which may not have fully captured what the participants believed about CF. Furthermore, the items could have been misunderstood by some of the participants, producing nonrepresentative findings as a result. Despite these shortcomings, questionnaires represent the most common tool to identify beliefs and allow for a large number of people to be surveyed at once.

Future research into learner beliefs about CF would benefit from questionnaires that include an open-ended component (e.g., Loewen et al., 2009) to allow participants to express their opinions on the topic. Incorporating qualitative-type interviews and/or observations are also likely to provide a more detailed picture of beliefs. Finally, future studies into learner beliefs about CF should survey other populations, age groups, and target languages. Possible connections between CF beliefs and learning outcomes should also be considered.

\section{Notes}

1 The BALLI has recently been updated (Horwitz, 2013, cited in Horwitz, 2015) to include 10 new items (for a total of 44 items) that probe learners' ideas about native-speaking teachers, learner autonomy, and their standardized language tests.

2 To complete the English core requirement, the college requires that all students take two ESL courses. Although these can be taken at any time during the period of their studies, the order in which they are pursued is predetermined. The first course is usually general in focus and targets learners' ability to speak, write, listen, and read in English. The second course, in turn, is more specific to the students' program and works on improving their knowledge of English necessary for the work force or university studies.

3 But see Nayar (1997) for a discussion on the binary nature of the ESL/EFL dichotomy and the need for an additional classification of English as an Associate Language (EAL).

4 The MWW test was used to verify whether the two samples could have come from the same generalized population (i.e., that Canadian and Russian learners had the same underlying distributions) against the alternative that one population tended to have larger values than the other. Because it is a nonparametric test, means were not computed.

5 While the established $p$-value in social sciences is .05, other disciplines allow less stringent alpha levels. Because the finding regarding the connection between gender and recasts appeared tantalizing (especially in a study on beliefs), the decision to report this result was made.

6 This "set of tactics" includes setting goals, choosing materials and tasks, planning practice opportunities, and monitoring and evaluating progress (Cotterall, 1995, p. 195).

\section{Acknowledgements}

I would like to express my deepest gratitude to the participants of this study for their time and willingness to contribute to the project. I am also grateful to the anonymous TESL Canada Journal reviewers for their valuable comments and suggestions. Any errors that remain are, of course, my own. 


\section{Author}

Eva Kartchava is Assistant Professor of Applied Linguistics and TESL at Carleton University. Her research interests include noticeability and effectiveness of corrective feedback in the classroom setting as well as teacher cognition and education.

\section{References}

Allen, P., Swain, M, Harley, B., \& Cummins, J. (1990). Aspects of classroom treatment: Toward a more comprehensive view of second language education. In: Harley, B. et al. (Eds.), The development of second language proficiency (pp. 57-81). Cambridge:, England Cambridge University Press. http://dx.doi.org/10.1017/cbo9781139524568.007

Almarza, G. G. (1996). Student foreign language teacher's knowledge growth. In D. Freeman \& J. C. Richards (Eds.), Teacher learning in language teaching (pp. 50-78). New York, NY: Cambridge University Press.

Ammar, A., \& Spada, N. (2006). One size fits all? Recasts, prompts and L2 learning. Studies in Second Language Acquisition, 28(4), 543-574. http://dx.doi.org/10.1017/s0272263106060268

Bacon, S. M. C., \& Finnemann, M. D. (1992). Sex differences in self-reported beliefs about language learning and authentic oral and written input. Language Learning, 42(4), 471-495. http:// dx.doi.org/10.1111/j.1467-1770.1992.tb01041.x

Bang, Y. (1999). Reactions of EFL learners to oral error correction. Journal of Pan-Pacific Association of Applied Linguistics, 3, 39-51.

Barcelos, A. M. F., \& Kalaja, P. (2011). Introduction to beliefs about SLA revisited. System, 39(3), 281-289. http://dx.doi.org/10.1016/j.system.2011.07.001

Basturkmen H. (2012). Review of research into the correspondence between language teachers' stated beliefs and practices. System, 40(2), 282-295. http://dx.doi.org/10.106/j.system.2012.05.001

Basturkmen, H., Loewen, S., \& Ellis, R. (2004). Teachers' stated beliefs about incidental focus on form and their classroom practices. Applied Linguistics, 25(2), 243-272. http://dx.doi. org/10.1093/applin/25.2.243

Bernat, E., \& Lloyd, R. (2007). Exploring the gender effect on EFL learners` beliefs about language learning. Australian Journal of Educational and Developmental Psychology, 7, 79-91.

Breen, M. P. (2001). Learner contributions to language learning: New directions in research. Harlow, England: Pearson Education.

Brown, A. (2009). Students` and teachers ' perceptions of effective foreign language teaching: A comparison of ideals. The Modern Language Journal, 93(1), 46-60. http://dx.doi.org/10.1111/ j.1540-4781.2009.00827.x

Cameron, L. J. (1990). Staying within the script: Personality and self-directed learning. System, 18, 65-75. http://dx.doi.org/10.1016/0346-251x(90)90029-5

Carroll, S., \& Swain, M. (1993). Explicit and implicit negative feedback: An empirical study of the learning of linguistic generalizations. Studies in Second Language Acquisition, 15, 357-386. http://dx.doi.org/10.1017/s0272263100012158

Cathcart, R. L., \& Olsen, J. E. W. B. (1976). Teachers' and students' preferences for correction of classroom conversation errors. In J. F. Fanselow \& R. H. Crymes (Eds.), On TESOL '76 (pp. 41-53). Washington, DC: TESOL.

Chavez, M. (2007). Students' and teachers' assessments of the need for accuracy in the oral production of German as a foreign language. The Modern Language Journal, 91, 537-563. http:// dx.doi.org/10.1111/j.1540-4781.2007.00622.x

Chenoweth, N. A., Day, R.R., Chun, A.E., \& Luppescu, S. (1983). Attitudes and preferences of ESL students to error correction. Studies in Second Language Acquisition, 6(1), 79-87. http://dx.doi. org/10.1017/s0272263100000310

Cotterall, L. S. (1995). Readiness for autonomy: Investigating learner beliefs. System, 23, 195-205. http://dx.doi.org/10.1016/0346-251x(95)00008-8 
Cotterall, L. S. (1999). Key variables in language learning: What do learners believe about them? System, 27, 473-492. http://dx.doi.org/10.1016/s0346-251x(99)00047-0

DeCoster, J. (1998). Overview of factor analysis. Retrieved from http://www.stat-help.com/notes. html

Dörnyei, Z. (2005). The psychology of the language learner: Individual differences in second language acquisition. Mahwah, NJ: Lawrence Erlbaum. http://dx.doi.org/10.4324/9781410613349

Dörnyei, Z., \& Ryan, S. (2015). The psychology of the language learner revisited. New York, NY: Routledge.

Dunstan, J. (1994). Education. In Cambridge encyclopedia of Russia and the Soviet Union (pp. 472477). Cambridge, England: Cambridge University Press.

Ehrman, M. E., \& Oxford, R. (1990). Adult language learning styles and strategies in an intensive training setting. Modern Language Journal, 79(1), 67-89. http://dx.doi.org/10.2307/327627

Ellis, R. (2006). Researching the effects of form-focussed instruction on L2 acquisition. AILA Review, 19, 18-41. http://dx.doi.org/10.1075/aila.19.04ell

Farrar, M. J. (1990). Discourse and the acquisition of grammatical morphemes. Journal of Child Language, 17, 607-624. http://dx.doi.org/10.1017/s0305000900010904

Field, A. (2005). Discovering statistics using SPSS. London, England: Sage.

Fox, C. A. (1993). Communicative competence and beliefs about language among graduate teaching assistants in French. Modern Language Journal, 77, 313-324. http://dx.doi. org/10.1111/j.1540-4781.1993.tb01977.x

Gouvernement du Québec. (2007a). Programme de formation de l'école québécoise: Education préscolaire, enseignement primaire (version approuvée). Québec, QC: Gouvernement du Québec, Ministère de L'Éducation, du Loisir et du Sport.

Gouvernement du Québec. (2007b). Programme de formation de l'école québécoise: Enseignement secondaire, premier cycle. Québec, QC: Gouvernement du Québec, Ministère de L'Éducation, du Loisir et du Sport.

Gouvernement du Québec. (2007c). Programme de formation de l'école québécoise: Enseignement secondaire, deuxième cycle. Québec, QC: Gouvernement du Québec, Ministère de L'Éducation, du Loisir et du Sport.

Han, Z. (2002). A study of the impact of recasts on tense consistency in L2 output. TESOL Quarterly, 36, 543-572. http://dx.doi.org/10.2307/3588240

Havranek, G. (2003). When is corrective feedback most likely to succeed? International Journal of Education Research, 37, 255-270. http://dx.doi.org/10.1016/S0883-0355(03)00004-1

Horwitz, E. K. (1985). Using student beliefs about language learning and teaching in the foreign language methods course. Foreign Language Annals, 18(4), 333-340. http://dx.doi. org/10.1111/j.1944-9720.1985.tb01811.x

Horwitz, E. K. (1987). Surveying student beliefs about language teaming. In A. L. Wenden \& J. Robin (Eds.), Learner strategies in language learning (pp. 119-132). London, England: Prentice Hall.

Horwitz, E. K. (1988). The beliefs about language learning of beginning university foreign language students. Modern Language Journal, 72(3), 283-294. http://dx.doi.org/10.1111/j.1540-4781.1988. tb04190.x

Horwitz, E. K. (1990). Attending to the affective domain in the foreign language classroom. In S. Magnan (Ed.), Shifting the instructional focus to the learner (pp. 15-33). Northeast Conference on the Teaching of Foreign Languages, Middlebury, VT.

Horwitz, E. K. (1999). Cultural and situational influences on foreign language learners' beliefs about language learning: a review of BALLI studies. System, 27(4), 557-576. http://dx.doi. org/10.1016/S0346-251X(99)00050-0

Horwitz, E. K. (2015). Beliefs about language learning and the experience of second language learning: Asking useful questions about language learning. In H. M. McGarrell and D. Wood (Eds.), CONTACT- Refereed Proceedings of TESL Ontario Research Symposium, 41(2), 2030. Retrieved from http://www.teslontario.net/uploads/publications/researchsymposium/ ResearchSymposium2015.pdf 
Jean, G., \& Simard. D. (2011). Grammar learning in English and French L2: Students'and teachers' beliefs and perceptions. Foreign Language Annals, 44(3), 467-494. http://dx.doi.org/10.1111/ j.1944-9720.2011.01143.x

Kalaja, P., \& Barcelos, A. M. F. (2003). Beliefs about SLA: New research approaches. Dordrecht, Netherlands: Kluwer Academic Press. http://dx.doi.org/10.1007/978-1-4020-4751-0

Kartchava, E., \& Ammar, A. (2014). Learners' beliefs as mediators of what is noticed and learned in the language classroom. TESOL Quarterly, 48(1), 86-109. http://dx.doi.org/10.1002/tesq.101.

Kern, R. G. (1995). Students' and teachers' beliefs about language learning. Foreign Language Annals, 28, 71-92. http://dx.doi.org/10.1111/j.1944-9720.1995.tb00770.x

Knowles, M. (1976). The modern practice of adult education. Chicago, IL: Association Press.

Kumaravadivelu, B. (1991). Language-learning tasks: teacher intention and learner interpretation. ELT Journal, 45(2), 98-107. http://dx.doi.org/10.1093/elt/45.2.98

Lasagabaster, D. \& Sierra, J. M. (2005). Error correction: Students`versus teachers` perceptions. Language Awareness, 14, 112-127. http://dx.doi.org/10.1080/09658410508668828

Leeman, J. (2003). Recasts and second language development: Beyond negative evidence. Studies in Second Language Acquisition, 25(1), 37-63. http://dx.doi.org/10.1017/s0272263103000020

$\mathrm{Li}, \mathrm{S}$. (2010). The effectiveness of corrective feedback in SLA: A meta-analysis. Language Learning, 60(2), 309-365. http://dx.doi.org/10.1111/j.1467-9922.2010.00561.x

Lochtman, K. (2002). Oral corrective feedback in the foreign language classroom: How it affects interaction in analytic foreign language teaching. International Journal of Educational Research, 37(3), 271-283. http://dx.doi.org/10.1016/s0883-0355(03)00005-3

Loewen, S., Li, S., Fei, F., Thompson, A., Nakatsukasa, K., Ahn, S., \& Chen, X. (2009). Second language learners' beliefs about grammar instruction and error correction. The Modern Language Journal, 93, 91-104. http://dx.doi.org/10.1111/j.1540-4781.2009.00830.x

Long, M. (1983). Native speaker/ non-native speaker conversation and negotiation of comprehensible input. Applied Linguistics, 4(2), 126-141. http://dx.doi.org/10.1093/applin/4.2.126

Long, M. (1996). The role of the linguistic environment in second language acquisition. In W. Ritchie and T. K. Bhatia (Eds.), Handbook of language acquisition (pp. 413-468). San Diego, CA: Academic Press. http://dx.doi.org/10.1016/b978-012589042-7/50015-3

Long, M. H. (2006). Problems in SLA. New York, NY: Lawrence Erlbaum.

Lyster, R. (2004). Differential effects of prompts and recasts on form-focused instruction. Studies in Second Language Acquisition, 26(3), 399-432. http://dx.doi.org/10.1017/s0272263104263021

Lyster, R., \& Izquierdo, J. (2009). Prompts versus recasts in dyadic interaction. Language Learning, 59(2), 453-498. http://dx.doi.org/10.1111/j.1467-9922.2009.00512.x

Lyster, R., \& Ranta, L. (1997). Corrective feedback and learner uptake: Negotiation of form in communicative classrooms. Studies in Second Language Acquisition, 19(1), 37-61. http://dx.doi. org/10.1017/s0272263197001034

Lyster, R., \& Saito, K. (2010). Oral feedback in classroom SLA: A meta-analysis. Studies in Second Language Acquisition, 32(2), 265-302. http://dx.doi.org/10.1017/s0272263109990520

Lyster R., Saito, K., \& Sato, M. (2013). Oral corrective feedback in second language classrooms. Language Teaching, 46(1), 1-40. http://dx.doi.org/10.1017/S0261444812000365

Mackey, A., \& Goo, J. (2007). Interaction research in SLA: a meta-analysis and research synthesis. In A. Mackey (Ed.), Conversational interaction in second language acquisition: A collection of empirical studies (pp. 407-452). Oxford, England: Oxford University Press. http://dx.doi. org/10.1002/9781405198431.wbeal0551

Mackey, A., \& Philp, J. (1998). Conversational interaction and second language development: Recasts, responses, and red herrings? The Modern Language Journal, 82(3), 338-356. http:// dx.doi.org/10.1111/j.1540-4781.1998.tb01211.x

Mattioli, G. (2004). On native language intrusions and making do with words: Linguistically homogeneous classes and native language use. English Teaching Forum, 42(4), 20-25.

McDonough, K. (2007). Interactional feedback and the emergence of simple past activity verbs in L2 English. In A. Mackey (Ed.), Conversational interaction in second language acquisition: A 
collection of empirical studies (pp. 323-338). Oxford, England: Oxford University Press.

Mohamed Hassan Mohamed, R. (2011). Les croyances des enseignants et des apprenants adultes quant à la rétroaction corrective à l'oral et la pratique réelle en classe de français langue étrangère en Égypte. Unpublished doctoral dissertation, University of Montreal.

Mori, Y. (1999). Epistemological beliefs and language learning beliefs: What do language learners believe about their learning? Language Learning, 49, 377-415. http://dx.doi.org/10.1111/00238333.00094

Nassaji, H., \& Fotos, S. (2011). Teaching grammar in second language classrooms: Integrating FormFocused Instruction in communicative context. London, England: Routledge.

Nayar, P. B. (1997). ESL/EFL Dichotomy Today: Language Politics or Pragmatics? TESOL Quarterly, 31, 9-37. http://dx.doi.org/10.2307/3587973

Nicholas, H., Lightbown, P. M., \& Spada, N. (2001). Recasts as feedback to language learners. Language Learning, 51, 719-758. http://dx.doi.org/10.1111/0023-8333.00172

Nunan, D. (1989). Hidden agendas: The role of the learner in programme implementation. In R. Johnson (eE.), The second language curriculum (pp. 176-186). Cambridge, England: Cambridge University Press. http://dx.doi.org/10.1017/cbo9781139524520.013

Oladejo, J. (1993). Error correction in ESL: Learners' preferences. TESL Canada Journal, 10(2), 7189. http://dx.doi.org/10.18806/tesl.v10i2.619

Oxford, R., Nyikos, M., \& Ehrman, M. E. (1988). Vive la difference? Reflections on sex differences in use of language learning strategies. Foreign Language Annals, 21(4), 321-329. http://dx.doi. org/10.1111/j.1944-9720.1988.tb01076.x

Panova, I., \& Lyster, R. (2002). Patterns of corrective feedback and uptake in an adult ESL classroom. TESOL Quarterly, 36(4), 573-595. http://dx.doi.org/10.2307/3588241

Peacock, M. (1999). Beliefs about language learning and their relationship to proficiency. International Journal of Applied Linguistics, 9(2), 247-265. http://dx.doi. org/10.1111/j.1473-4192.1999.tb00175.x

Peacock, M. (2001). Pre-service ESL teachers' beliefs about second language learning: A longitudinal study. System, 29, 177-195. http://dx.doi.org/10.1016/S0346-251X(01)00010-0

Philp, J. (2003). Constraints on "noticing the gap": Nonnative speakers' noticing of recasts in NSNNS interaction. Studies in Second Language Acquisition, 25, 99-126. http://dx.doi.org/10.1017/ s0272263103000044

Rifkin, B. (2000). Revising beliefs about foreign language learning. Foreign Language Annals, 33(4), 394-420. http://dx.doi.org/10.1111/j.1944-9720.2000.tb00621.x

Russell, J., \& Spada, N. (2006). The effectiveness of corrective feedback for second language acquisition: A meta-analysis of the research. In J. Norris \& L. Ortega (Eds.), Synthesizing research on language learning and teaching (pp. 131-164). Amsterdam: John Benjamins. http:// dx.doi.org/10.1075/11lt.13.09val

Russell, V. (2009). Corrective feedback, over a decade of research since Lyster \& Ranta (1997): Where do we stand today? Electronic Journal of Foreign Language Teaching, 6(1), 21-31.

Schulz, R. A. (1996). Focus on form in the foreign language classroom: students' and teachers' views on error correction and the role of grammar. Foreign Language Annals, 29(3), 343-364. http://dx.doi.org/10.1111/j.1944-9720.1996.tb01247.x

Schulz, R. A. (2001). Cultural differences in student and teacher perceptions concerning the role of grammar instruction and corrective feedback: USA - Columbia. The Modern Language Journal, 85(2), 244-258. http://dx.doi.org/10.1111/0026-7902.00107

Sheen, Y. (2004). Corrective feedback and learner uptake in communicative classrooms across instructional settings. Language Teaching Research, 8, 263-300. http://dx.doi. org/10.1191/1362168804lr146oa

Sheen, Y. (2006). Exploring the relationship between characteristics of recasts and learner uptake. Language Teaching Research, 10(4), 361-392. http://dx.doi.org/10.1191/13621688061r203oa

Siebert, L. L. (2003). Student and teacher beliefs about language learning. The ORTESOL Journal, 21, 7-39. 
Simon, E. \& Taverniers, M. (2011). Advanced EFL learners` beliefs about language learning and teaching: A comparison between grammar, pronunciation, and vocabulary. English Studies, 92(8), 896-922. http://dx.doi.org/10.1080/0013838X.2011.604578

Slimani, A. (1991). Evaluation of classroom interaction. In C. Anderson \& A. Berretta (Eds.), Evaluating second language education (pp. 197-220). Cambridge, England: Cambridge University Press. http://dx.doi.org/10.1017/cbo9781139524575.009

Statistics Canada. (2011). Language composition of Canada: Highlight tables, 2011 census. Retrieved from http://www.statcan.gc.ca/tables-tableaux/sum-som/101/cst01/demo11b-eng.htm

Stern, H. H. (1975). What can we learn from the good language learner? Canadian Modern Language Review, 31, 304-318.

Tanaka, K. (2004). Changes in Japanese students' beliefs about language learning and English language proficiency in a study-abroad context. Unpublished doctoral dissertation, University of Auckland.

Tanaka, K., \& Ellis, R. (2003). Study-abroad, language proficiency, and learner beliefs about language learning. JALT Journal, 25, 63-83.

Tercanlığlu, L. (2005). Pre-service EFL teachers' beliefs about foreign language learning and how they relate to gender. Electronic Journal of Research in Educational Psychology, 5(3.1), 145- 162.

Tudor, I. (1993). Teacher roles in the learner-centred classroom. ELT Journal, 47(1), 22-31. http:// dx.doi.org/10.1093/elt/47.1.22

Ushinsky, K. D. (1988). Pedagogicheskiye sochineniya. In S. F. Yegorov (Ed.), Pedagogiga. Moscow.

Ustinova, I. P. \& Bhatia, T. K. (2005). Convergence of English in Russian TV commercials. World Englishes, 24(4), 495-508. http://dx.doi.org/10.1111/j.0883-2919.2005.00433.x

Victori, R. M. (1992). Investigating the metacognitive knowledge of students of English as a second language. Unpublished Master's Thesis. Department of TESOL and Applied Linguistics, University of California, Los Angeles.

Wenden, A. (1991). Learner strategies for learner autonomy. New York, NY: Prentice Hall.

Wenden, A. (1999). An introduction to metacognitive knowledge and beliefs in language learning: Beyond the basics. System, 27, 435-441. http://dx.doi.org/10.1016/s0346-251x(99)00043-3

Winer, L. (2007). No ESL in English schools: Language policy in Quebec and implications for TESL teacher education. TESOL Quarterly, 41, 489-508. http://dx.doi.org/10.1002/j.1545-7249.2007. tb00082.x

Yang, J. S., \& Kim, T. Y. (2011). Sociocultural analysis of second language learner beliefs: a qualitative case study of two study-abroad ESL learners. System, 39(3), 325-334. http://dx.doi. org/10.1016/j.system.2011.07.005

Yang, N. D. (1999). The relationship between EFL learners' belies and learning strategy use. System, 27, 515-535. http://dx.doi.org/10.1016/S0346-251X(99)00048-2

Yoshida, R. (2008). Teachers' choice and learners' preference for corrective-feedback types. Language Awareness, 17(1), 78-93. http://dx.doi.org/10.2167/la429.0

\section{Appendix \\ Beliefs Questionnaire}

\section{Part 1: Background}

\section{Gender: Male $\square$ Female}

2. Age:

3. Languages:

a. What is your native language?

b. Including your native language, how many languages do you speak?

Please indicate them in the space provided.

a.

b.

c. 
c. How long have you been learning English (number of hours)?

d. For each language, indicate:

\begin{tabular}{|c|c|c|c|c|c|c|c|c|c|c|c|c|c|c|}
\hline $\begin{array}{l}\text { Lan- } \\
\text { guage }\end{array}$ & $\begin{array}{l}\text { Where } \\
\text { did you } \\
\text { learn } \\
\text { (school, } \\
\text { home, } \\
\text { courses, } \\
\text { etc.)? }\end{array}$ & $\begin{array}{l}\frac{\text { How }}{\text { long }} \\
\text { have you } \\
\text { spoken } \\
\text { the lan- } \\
\text { guage (in } \\
\text { years)? }\end{array}$ & \multicolumn{3}{|c|}{$\begin{array}{l}\text { How well do } \\
\text { you write } \\
\text { in the lan- } \\
\text { guage? }\end{array}$} & \multicolumn{3}{|c|}{$\begin{array}{l}\text { How well do } \\
\text { you speak } \\
\text { in the lan- } \\
\text { guage? }\end{array}$} & \multicolumn{2}{|c|}{$\begin{array}{l}\text { How well do } \\
\text { you listen } \\
\text { in the lan- } \\
\text { guage? }\end{array}$} & 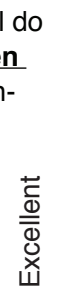 & \multicolumn{3}{|c|}{$\begin{array}{l}\text { How well do } \\
\text { you read } \\
\text { in the lan- } \\
\text { guage? }\end{array}$} \\
\hline \multicolumn{15}{|l|}{ Native } \\
\hline \multicolumn{15}{|l|}{ English } \\
\hline \multicolumn{15}{|l|}{ «A » } \\
\hline \multicolumn{15}{|l|}{ «B » } \\
\hline «C & & & & & & & & & & & & & & \\
\hline
\end{tabular}

\section{Part 2}

Indicate how well you agree with each of the following statements. Please select your answer on the scale to the right of each statement, where $1=$ STRONGLY DISAGREE and $5=$ STRONGLY AGREE. Please use the entire scale in making your decisions and answer all the questions.

Example:

\begin{tabular}{lccccc}
\hline & \multicolumn{1}{c}{$\begin{array}{c}\text { Strongly } \\
\text { disagree }\end{array}$} & & \multicolumn{2}{c}{$\begin{array}{c}\text { Strongly } \\
\text { agree }\end{array}$} \\
\hline $\begin{array}{l}\text { Teachers should teach pronunciation in } \\
\text { language classes. }\end{array}$ & 1 & (2) & 3 & 4 & 5 \\
\hline
\end{tabular}

This indicates that you disagree with the statement.

\begin{tabular}{|c|c|c|c|c|c|}
\hline & $\begin{array}{l}\text { Strongly } \\
\text { disagree }\end{array}$ & & & & \\
\hline $\begin{array}{l}\text { 1. I learn when the teacher corrects the errors of } \\
\text { other students in the class. }\end{array}$ & 1 & 2 & 3 & 4 & 5 \\
\hline $\begin{array}{l}\text { 2. Correction of spoken errors in English makes } \\
\text { me nervous. }\end{array}$ & 1 & 2 & 3 & 4 & 5 \\
\hline $\begin{array}{l}\text { 3. Encouraging learners to correct themselves is } \\
\text { beneficial for beginning students. }\end{array}$ & 1 & 2 & 3 & 4 & 5 \\
\hline $\begin{array}{l}\text { 4. The English teacher should orally correct } \\
\text { grammatical errors only if those errors } \\
\text { interfere with understanding. }\end{array}$ & 1 & 2 & 3 & 4 & 5 \\
\hline $\begin{array}{l}\text { 5. When correcting speaking errors, the teacher } \\
\text { should not use negative words (e.g.: "All } \\
\text { that you are saying is wrong" or "You don't } \\
\text { understand anything" or "You don't know } \\
\text { anything"). }\end{array}$ & 1 & 2 & 3 & 4 & 5 \\
\hline $\begin{array}{l}\text { 6. Having teacher provide the correct form is } \\
\text { beneficial for beginning students. }\end{array}$ & 1 & 2 & 3 & 4 & 5 \\
\hline
\end{tabular}




\begin{tabular}{|c|c|c|c|c|c|c|}
\hline \multirow[b]{2}{*}{7.} & \multirow[b]{2}{*}{$\begin{array}{l}\text { Correction of spoken errors is essential in an } \\
\text { English class. }\end{array}$} & \multicolumn{3}{|c|}{$\begin{array}{l}\text { Strongly } \\
\text { disagree }\end{array}$} & \multicolumn{2}{|c|}{$\begin{array}{r}\text { Strongly } \\
\text { agree }\end{array}$} \\
\hline & & 1 & 2 & 3 & 4 & 5 \\
\hline 8. & $\begin{array}{l}\text { An error is an indication of what I still do not } \\
\text { know in English. }\end{array}$ & 1 & 2 & 3 & 4 & 5 \\
\hline 9. & It is important to correct written errors. & 1 & 2 & 3 & 4 & 5 \\
\hline 10. & $\begin{array}{l}\text { Different techniques need to be used to } \\
\text { correct spoken errors in English. }\end{array}$ & 1 & 2 & 3 & 4 & 5 \\
\hline 11. & $\begin{array}{l}\text { Having teacher provide the correct form is the } \\
\text { best technique to correct vocabulary errors in } \\
\text { English. }\end{array}$ & 1 & 2 & 3 & 4 & 5 \\
\hline 12. & $\begin{array}{l}\text { Having teacher provide the correct form is the } \\
\text { best technique to correct grammatical errors } \\
\text { in English. }\end{array}$ & 1 & 2 & 3 & 4 & 5 \\
\hline 13. & It is important to correct spoken errors. & 1 & 2 & 3 & 4 & 5 \\
\hline 14. & $\begin{array}{l}\text { Regarding my spoken errors in English, I } \\
\text { prefer that my teacher tells me explicitly that } \\
\text { my statement is incorrect and gives me the } \\
\text { correct form. }\end{array}$ & 1 & 2 & 3 & 4 & 5 \\
\hline 15. & $\begin{array}{l}\text { Pushing students to correct their own errors } \\
\text { helps them to learn English. }\end{array}$ & 1 & 2 & 3 & 4 & 5 \\
\hline 16. & $\begin{array}{l}\text { If the teacher does not correct my speaking } \\
\text { errors, my determination to learn English will } \\
\text { diminish. }\end{array}$ & 1 & 2 & 3 & 4 & 5 \\
\hline 17. & $\begin{array}{l}\text { The teacher must tell the student about his/ } \\
\text { her problems in English to help the student } \\
\text { master them. }\end{array}$ & 1 & 2 & 3 & 4 & 5 \\
\hline 18. & $\begin{array}{l}\text { Having the teacher provide the correct form } \\
\text { is the best technique to correct pronunciation } \\
\text { errors in English. }\end{array}$ & 1 & 2 & 3 & 4 & 5 \\
\hline 19. & $\begin{array}{l}\text { The teacher of English should repeat my } \\
\text { spoken error by adjusting the intonation of his/ } \\
\text { her voice to highlight the error and to ensure } \\
\text { that I correct myself. }\end{array}$ & 1 & 2 & 3 & 4 & 5 \\
\hline 20. & $\begin{array}{l}\text { I expect my teacher to correct my vocabulary } \\
\text { errors in English. }\end{array}$ & 1 & 2 & 3 & 4 & 5 \\
\hline 21. & $\begin{array}{l}\text { If the teacher lets the students make mistakes } \\
\text { from the beginning, it will be difficult to correct } \\
\text { them later on. }\end{array}$ & 1 & 2 & 3 & 4 & 5 \\
\hline 22. & $\begin{array}{l}\text { I like it when the teacher corrects me in the } \\
\text { English class. }\end{array}$ & 1 & 2 & 3 & 4 & 5 \\
\hline 23. & $\begin{array}{l}\text { I expect my teacher to correct my grammatical } \\
\text { errors in English. }\end{array}$ & 1 & 2 & 3 & 4 & 5 \\
\hline 24. & $\begin{array}{l}\text { The choice of the technique with which to } \\
\text { correct errors should depend on my level of } \\
\text { proficiency. }\end{array}$ & 1 & 2 & 3 & 4 & 5 \\
\hline
\end{tabular}




\begin{tabular}{|c|c|c|c|c|c|c|}
\hline \multirow[b]{2}{*}{25.} & \multirow[b]{2}{*}{$\begin{array}{l}\text { I expect my teacher to correct my } \\
\text { pronunciation errors in English. }\end{array}$} & \multicolumn{3}{|c|}{$\begin{array}{l}\text { Strongly } \\
\text { disagree }\end{array}$} & \multicolumn{2}{|c|}{$\begin{array}{r}\text { Strongly } \\
\text { agree }\end{array}$} \\
\hline & & 1 & 2 & 3 & 4 & 5 \\
\hline 26. & $\begin{array}{l}\text { Correction of spoken errors in English is an } \\
\text { excellent way to promote communication } \\
\text { among students. }\end{array}$ & 1 & 2 & 3 & 4 & 5 \\
\hline 27. & $\begin{array}{l}\text { The teacher of English should correct spoken } \\
\text { errors at the end of a lesson. }\end{array}$ & 1 & 2 & 3 & 4 & 5 \\
\hline 28. & $\begin{array}{l}\text { I prefer to be corrected by my classmates in } \\
\text { the English class. }\end{array}$ & 1 & 2 & 3 & 4 & 5 \\
\hline 29. & $\begin{array}{l}\text { The teacher should correct all the spoken } \\
\text { errors that students make in the English class. }\end{array}$ & 1 & 2 & 3 & 4 & 5 \\
\hline 30. & $\begin{array}{l}\text { Teachers of English should correct spoken } \\
\text { errors as soon as they are made. }\end{array}$ & 1 & 2 & 3 & 4 & 5 \\
\hline 31. & $\begin{array}{l}\text { The teacher of English should correct only } \\
\text { those spoken errors that occur repeatedly. }\end{array}$ & 1 & 2 & 3 & 4 & 5 \\
\hline 32. & $\begin{array}{l}\text { Correction of spoken errors in English draws } \\
\text { my attention to the correct form given by my } \\
\text { teacher. }\end{array}$ & 1 & 2 & 3 & 4 & 5 \\
\hline 33. & $\begin{array}{l}\text { Encouraging learners to correct themselves is } \\
\text { beneficial for students at the advanced level. }\end{array}$ & 1 & 2 & 3 & 4 & 5 \\
\hline 34. & $\begin{array}{l}\text { I want my teacher of English to encourage me } \\
\text { to correct myself. }\end{array}$ & 1 & 2 & 3 & 4 & 5 \\
\hline 35. & $\begin{array}{l}\text { Correction of spoken errors in the English } \\
\text { class creates a negative attitude toward the } \\
\text { study of English. }\end{array}$ & 1 & 2 & 3 & 4 & 5 \\
\hline 36. & $\begin{array}{l}\text { Having the teacher provide the correct form } \\
\text { is beneficial for the students at the advanced } \\
\text { level. }\end{array}$ & 1 & 2 & 3 & 4 & 5 \\
\hline 37. & $\begin{array}{l}\text { Without the teacher's correction of my spoken } \\
\text { errors, I cannot make the connection between } \\
\text { the grammar rule and its use. }\end{array}$ & 1 & 2 & 3 & 4 & 5 \\
\hline 38. & $\begin{array}{l}\text { The teacher should correct only those } \\
\text { pronunciation errors that make comprehension } \\
\text { difficult. }\end{array}$ & 1 & 2 & 3 & 4 & 5 \\
\hline 39. & $\begin{array}{l}\text { The teacher should always provide a } \\
\text { commentary or linguistic information to help } \\
\text { me correct myself. }\end{array}$ & 1 & 2 & 3 & 4 & 5 \\
\hline 40. & $\begin{array}{l}\text { Having teacher provide the correct form is } \\
\text { the best technique to correct spoken errors in } \\
\text { English. }\end{array}$ & 1 & 2 & 3 & 4 & 5 \\
\hline
\end{tabular}

